Константин Григоричев

\title{
«НЕПРАВИЛЬНЫЕ» КИТАЙЦЫ И «ЗАХВАЧЕННЫЙ» ГОРОД: ОСПАРИВАНИЕ ГОРОДСКОГО ПРОСТРАНСТВА КАК ВЫРАБОТКА ПРАКТИК ВЗАИМОДЕЙСТВИЯ С ДРУГИМ
}

На материалах Иркутска анализируется процесс конструирования оспариваемых городских пространств в связи с изменением миграционного потока из КНР. Анализ построен на основе двух серий полуформализованных интервью в логике идей «права на город» Дэвида Харви, Анри Лефевра, Дона Митчела и представлений Георга Зиммеля о чужаке. Проводится сравнительный анализ двух типов городских локальностей, определяемых горожанами в качестве «мигрантских» и «китайских». В городе, знакомом с миграцией из Китая с конца 1980-х-начала 1990-х гг, сформировались устойчивые локальности, описываемые в качестве «китайских»: рынки, автомастерские, автомойки, лесопилки. «Китайскость» таких локальностей описывала не столько доминирующую группу, сколько репертуар допустимых практик взаимодействия с другим. Массовый въезд туристов из Китая в 2015-2019 гг. привел к появлению новых городских пространств, описываемых жителями и медиа в качестве «китайских». Такие локальности получили иные визуальные маркеры, которые стали символом нарушения сложившейся ранее конвенции о возможных местах и способах взаимодействия горожан и мигрантов. Меняющаяся символика интерпретируется принимающим сообществом как признак изменения пространства репрезентаций и вторжение в «обжитое пространство» горожан. Если в первом случае «китайские» локальности выступают «местом встречи», площадкой совместного создания и использования городской инфраструктуры, то во втором- пространством конфликта, борьбы за город, выливающейся в локальные бои за историю. Парадоксальным образом ключевыми акторами в конструировании ситуации оспаривания пространства во втором случае оказываются

Григоричев Константин Вадимович- д.с.н., проректор по научной работе и международной деятельности, Иркутский государственный университет; в.н.с., Национальный исследовательский Томский государственный университет, Иркутск, Россия. Электронная почта: grigoritchev@yandex.ru 
горожане и местные медиа, тогда как мигранты включены в этот процесс лишь пассивно. Переопределение мигрантских локальностей города от места контакта к пространству оспаривания права на город может являться механизмом выработки нового спектра практик взаимодействия. Смена модели поведения Другого требует нового репертуара допустимых исполнений, и именно конфликт позволяет определить новые границы допустимого и одобряемого. Если приезжие не участвуют в конструировании такого конфликта, то за них это делают «местные».

Ключевые слова: мигрантские локальности, «китайскость», миграция, оспариваемые пространства

DOI: 10.17323/727-0634-2020-18-4-593-608

Быстрый рост туристического потока из Китая в Россию в 2015-2019 гг. привел к острой реакции на появление заметных групп китайцев на улицах городов. Алармистские оценки присутствия хорошо различимой мигрантской группы широко распространены как в давних туристических центрах страны, так и в городах, почти не сталкивавшихся с нею ранее (см.: Адамайтес 2018; Сальникова 2020). Настороженная и даже враждебная реакция на появление Другого в провинциальном российском городе, лишь начинающем постепенно включаться в глобальные трансграничные потоки, вероятно, вполне закономерна. Однако на этом фоне парадоксально выглядит воспроизведение сходной реакции в сибирских городах, давно и тесно знакомых с миграцией из Китая, для которых приток китайских туристов не означал появление новой или, по крайней мере, мало знакомой группы.

Иркутск в этом смысле представляет собой типичный сибирский город, в повседневности которого китайская миграция прочно присутствует уже около трёх десятилетий (Дятлов 2004). Сформировавшаяся еще на рубеже 1980-1990-х гг., эта миграция длительное время носила трудовой и торговый характер. Использование мигрантами из КНР иных категорий виз (учебной или туристической) часто становилось лишь инструментом легального въезда в Россию, а китайского «туриста» или «студента» легко можно было встретить на рынке или на стройке, и крайне затруднительно - у городских достопримечательностей или в вузе. Эта миграция стала одним из ключевых факторов, формировавших миграционный и «этнический» ландшафт сибирского и дальневосточного города. Формула «китайский мигрант», «китаец» стала не только описанием группы чужаков, но и емким определением их статуса, возможных моделей поведения и посещаемых городских локальностей.

Быстрый рост туристического потока из КНР стал шоком для иркутского обывателя и городских властей. Вместо привычного торговца, строителя или чернорабочего, замкнутого в пределах рынков, строек и промышленных объектов, иркутяне столкнулись с большими группами 
вполне обеспеченных китайских туристов, чей внешний вид, манера поведения и места пребывания разительно отличались от привычных. Ориентация туристов на магазины и рестораны, городские достопримечательности привела к необходимости нового понимания привычного горожанину определения «китайских» мест: «китайский рынок», «китайский ресторан», «китайский магазин». Вместе с переопределением содержания таких мест горожанам пришлось адаптироваться и к их новой географии: большинство новых локаций сосредоточения приезжих из КНР находится в частях города, где присутствие китайцев еще 5-7 лет назад было минимальным. В дискурсе местной прессы, электронных изданий и социальных медиа исторический центр города стремительно превратился в пространство, «скупленное» в результате «нашествия» туристов из Китая (напр., Старшинина 2016).

Вместе с тем в Иркутске радикальной туристификации центра (изменение функционала значительной части зданий или их частей в привлекательных для туристов локациях) не произошло. Фактически изменилась лишь целевая аудитория магазинов, ресторанов и кафе, а также существовавших ранее туристических объектов. Сегодня невозможно выделить «туристические» заведения, которые были бы ориентированы исключительно на приезжих, а китайские туристы здесь тесно соседствуют с другими «гостями города» и местными жителями. Не изменился и функционал нежилых помещений вдоль «зеленой линии» ${ }^{1}$ : магазины и кафе здесь чередуются с официальными учреждениями, деловыми центрами, зданиями университетов и жилыми домами. Иными словами, новое определение этих локальностей как пространства оспариваемого, «исключаемого» из привычного города связывается не с изменениями их функций, а с появлением новой мигрантской группы.

В этой статье анализируются механизмы появления в историческом центре Иркутска локальностей, которые в медийном и повседневном дискурсе интерпретируются как оспариваемые (Dürr 2002; Reyes 2016). Ключевым вопросом является субъектность этого процесса, роль в нем мигрантов и принимающего сообщества, его не рефлексируемые участниками смыслы. Важно понять, что служит символами «отчуждаемого», оспариваемого пространства, какое содержание привносят в него приезжие и как это содержание «считывается» горожанами в конкурентном контексте. Закономерным продолжением этих размышлений становится вопрос о динамике ситуации, перспективах ее развития на городской сцене.

Эмпирической основой статьи выступают две серии полевых наблюдений и неструктурированных либо полуформализованных интервью с горожанами (43 записи), взятых в Иркутске в 2014-2019 гг. Первый массив

\footnotetext{
${ }^{1}$ Основной туристический маршрут по историческим районам Иркутска, обозначенный по тротуару зеленой линией.
} 
интервью сформирован при исследовании представлений горожан о «китайских» локальностях Иркутска в 2014-2017 гг. и связан преимущественно с определением того, что маркирует эти локальности и формирует представления о «китайскости». В фокусе интервью находились «китайские» рынки и, в меньшей степени, иной «китайский» бизнес как пространство коммуникаций («сцена») и возможных на ней исполнений. «Китайскость» здесь рассматривалась как маркер фрейма, определяющего ситуацию в единстве социальной организации событий и действий (вовлеченности) ее участников (Гофман 2004: 71). Второй массив интервью собирался в 2017-2019 гг. в рамках изучения использования мигрантами городской инфраструктуры и отношениях горожан к мигрантам по этому поводу. При всем различии фокусов двух серий интервью, в обоих присутствовал спектр вопросов о визуальных маркерах, определяющих те или иные городские локальности в качестве мигрантских, «китайских», и рефлексии респондентов о спектре допустимых практик в таких локальностях.

Теоретической рамкой для анализа полевых материалов являются идеи права на город (Lefebvre 2000; Mitchell 2003; Harvey 2006), описывающие конкуренцию за символическую власть над общественными городскими пространствами, которые, в нашем случае, определяются горожанами в качестве «китайских» и «мигрантских». В центре анализа-представления жителей города об изменении функционала городского пространства, возможности доступа к нему, и права на участие в жизни городских локальностей (Lefebvre 2000: 158). Идеи о «вытеснении» жителей из мигрантских локальностей и ограничения доступа к городу, считываемые горожанами в новой визуальности, позволяют увидеть, как появление новой группы приезжих ведет к утрате горожанами (по крайней мере, в их представлении) прав на определение функций городского пространства, доминирующих в нем смыслов и образов, участия в жизни города.

Вместе с тем в центре моего внимания не городские пространства как таковые, а отношения горожан и мигрантов по поводу города. Очевидная разница между трудовыми мигрантами и туристами здесь отходит на второй план, а главное значение приобретает статус другого. Иными словами, в фокусе размышлений находятся не собственно городские пространства, их визуальная и/или функциональная эволюция, а изменения в системе взаимодействия принимающего сообщества с другим, отраженные в пространстве. Специфика ситуации заключается в том, что другой- не абсолютный незнакомец: в нем воплощается единство близости и удаленности (Зиммель 2008: 12). Китайцы для Иркутска стали привычной частью городской повседневности, тем чужаком, который является элементом самой группы (там же: 9) и выполняет жизненно необходимую функцию торговца, посредника (Краснопольская, Солодова 2012: 29). Смена функции, предписанной принимающим сообществом другому, обусловила конфликт, который закономерным образом получил 
пространственное выражение как символ социальных отношений (Зиммель 2008:9). Зиммелевское представление о чужаке, таким образом, выступает еще одной рамкой анализа, в перспективе которой появление в городе новых локальностей, маркируемых через чужака («китайцев», «мигрантов»), может фиксировать нарушение устоявшихся конвенций в отношениях мигрантов и городских сообществ.

В фокусе моего внимания - городские локальности, которые описываются горожанами в качестве «китайских». Поскольку Иркутск с конца 1980-х гг. оказался включен в миграцию из КНР (Григоричев и др. 2019), в городе сформировался устойчивый спектр локальностей, которые определялись жителями в качестве «китайских». С притоком туристов из Китая в 2015-2019 гг. в центре внимания городских медиа и обывателей оказались иные городские локации, которые связываются с присутствием приезжих из КНР. Это позволяет выделить два типа «китайских» мест Иркутска, которые с долей условности я обозначаю как «старые» и «новые китайские локальности». Для каждого типа локальностей выделялись визуальные и языковые маркеры, которые означают в глазах горожан «китайскость» этих мест. Названные респондентами приметы «китайских мест» фиксировались и сопоставлялись с точки зрения целевой аудитории.

\section{«Старые китайские локальности»: городское пограничье и место встречи}

Формирование системы «старых китайских локальностей» в Иркутске связано с началом масштабных трансграничных миграций из КНР на рубеже 1980-1990-х гг. Преобладание торговых стратегий среди мигрантов предопределило, что первым типом мигрантских локальностей постсоветского Иркутска стали розничные «китайские» рынки. «Китайскими» их делало общественное мнение, а не история возникновения и/или состав торговцев. Рынки быстро стали многонациональными, и их внутренняя структура нередко была непрозрачной даже для администрации (Дятлов 2014). Покупатели в пределах «китайского» рынка сталкивались с китайцами, киргизами, выходцами из Закавказья и российского Северного Кавказа, а также с горожанами, для которых рынок стал способом выживания. Собственно китайские торговцы быстро перестали выступать единственной, а затем и доминирующей торговой группой.

Из примитивного механизма торговли и выживания «китайские» рынки превратились в масштабный и значимый элемент городской инфраструктуры. Сеть крупных оптово-розничных и мелких рынков, охватывающих все основные районы Иркутска, стала способом восполнения дефицита торговой инфраструктуры советского города и одним из важнейших механизмов постсоветской трансформации городского пространства 
(Григоричев и др. 2019). После запрета иностранным гражданам торговать на открытых рынках (2007) процесс ухода китайских торговцев в тень резко ускорился. Сохраняя, фактически, торговый бизнес, китайские предприниматели вынуждены были работать через наемных продавцов-посредников, а сами, в большинстве случаев, в непосредственный контакт с горожанами не вступали. Для горожанина-покупателя китайцы перестали быть главными действующими лицами рынка, уступая сцену наемным продавцам: «Китайцы не выпячиваются, ведут себя достаточно скромно. Сидит, где-то контролирует несколько павильончиков, то есть он сидит вежливо в своей каморке» (м., около 45 лет, интервью 2014 г.).

Тем не менее в интервью 2014-2017 гг. именно «китайские» рынки определялись как основной элемент «китайского» Иркутска, выделяемые как средоточие «настоящей» китайскости и «настоящих» китайцев:

Знаете, если меня спросить, где найти китайцев, я сразу скажу-на рынке. Вот в эти все типа «китайские» рестораны не скажу, там нет китайцев, только буряты и узбеки всякие поварами, и еды китайской нету настоящей. Так что это на базар надо точно [идти] (м., около 23-25 лет, интервью 2014 г.).

«Старые китайские локальности» города фиксируются легко узнаваемыми визуальными маркерами, отражающими стереотипизированные представления о Китае: сочетание красного и желтого цветов, стилизация кириллического шрифта под иероглифическое письмо. Содержание вывесок может прямо противоречить их китайскому облику: например, на рынке «Китай-город» в подобном стиле оформлены вывески торгового павильона с товарами из Киргизии. В наружной рекламе часто встречаются очертания крыши пагоды, изображения драконов.

Менее масштабны, но не менее узнаваемы разнообразные «китайские» предприятия сферы услуг: автосервисы, автомойки, небольшие деревообрабатывающие производства («лесопилки»). Они наделяются свойствами, близкими к «китайским» рынкам и общепиту: дешевизной, большими порциями, в случае с китайскими банями- «много удовольствия за мало денег» (ж., 42 года, интервью 2017 г.), невысокими качеством товаров и невзыскательным сервисом. Визуальные маркеры здесь, как и на «китайских» рынках, отличаются лаконичностью и теми же стереотипными образами. Простоту и узнаваемость символов китайскости потребителями-горожанами можно определить как главную характеристику визуальных маркеров подобных «китайских» локальностей. Наиболее яркой иллюстрацией является рекламная вывеска автосервиса «Мастер Лю», на которой быстрый и недорогой авторемонт предлагает Джеки Чан-главный китаец голливудских боевиков.

Рынки и иные «старые китайские локальности» оставались в восприятии горожан местами концентрации подлинной китайскости, несмотря 
на очевидное противоречие используемого определения и их внутренней организации, состава торговцев, мест производства и поставки товаров, специфики общепита. Подлинность рыночной китайскости подчеркивалась развитыми практиками посещения горожанами полулегальных точек общепита - «чифанек» (чуфанек, чафанек). Именно здесь, по представлениям знатоков, было возможно попробовать аутентичную китайскую кухню, прикоснуться к «настоящему Китаю», а заодно погрузиться в «другой» город, скрытый от горожанина (Тимошкин 2018). Они прямо противопоставлялись легальному «этническому» общепиту, не представлявшей «аутентичной» кухни (Дятлова 2015).

Таким образом, состав торгующих и товаров, визуальность «старых китайских локальностей» свидетельствуют об отсутствии доминирования в них какой-либо этнической группы. Напротив, все эти признаки скорее маркируют реализацию в пространстве таких локальностей ситуации границы, в которой воспроизводятся практики пограничной контактной зоны вдали от собственно государственных границ. Именно контакт с «чужим» респонденты и определяли как «подлинную» китайскость. Для ее существования здесь присутствие самих китайцев перестает быть необходимым:

Даже если на китайском рынке скоро не будет китайцев, если ситуация такая сложится, то рынок все равно будет называться китайским... Знаете, скорее всего, «китайка»- это такой образ, уже закрепившийся в умах именно иркутян, что любой такой рынок, где работают любые мигранты, даже, например, не из Азии, именно не китайцы, а, например, из Средней Азии, тоже, наверное, «китайка» будет называться (м., 25 лет, интервью 2014 г.).

«Китайскость» выступает ключевым признаком описанных локальностей. Она является не столько характеристикой групп, сколько емким описанием способов взаимодействия принимаюеего сообщества с мигрантами в ситуации границы. Одновременно этими маркерами очерчиваются территориальные пределы локальностей, где одобряемы «пограничные» практики, недопустимые в иных частях города. Этим маркером определяется и сама сцена, и возможные здесь и только здесь исполнения.

Допустимость физического присутствия китайцев и признание за ними права на те или иные действия обусловлены именно спецификой городских локальностей. Такие локальности, сформировавшиеся как результат совместного конструирования городской инфраструктуры, превратились в своего рода пограничье, пространство ничье и одновременно общее. Устойчивая интерпретация их в качестве поля контакта мигрантов и горожан определяет набор взаимно допустимых исполнений, а стереотипизированная визуальность «старых китайских локальностей» ясно очерчивает физическое пространство сцены. 


\section{«Новые китайские локальности»: оспариваемое пространство}

Формирование «новых китайских локальностей» стало заметным с ростом въездного туризма из Китая, который начался в регионах Сибири с 2015 г. и стал особенно заметен в 2016-2017 гг. Уже весной 2016 г. региональные власти и медиа отмечали рост туристического потока почти в полтора раза. Однако быстрее и острее всех отреагировали на появление на городских улицах визуально заметных групп китайских туристов социальные сети и веб-форумы, запестревшие комментариями о «новой китайской угрозе»: «Нельзя китайцам к нам, уж хоть что мне говорите...»; «Уже половину Байкала скупили китайцыл»; «Едут туристами и остаются. На Сурнова жил в новостройке, на площадке шесть квартир, три из них китайць, причём живут семьями. Скоро как в Улан-Удэ будет половина русских» (комментарии к: Иркутск онлайн 2017).

В отличие от «старых», «новые «китайские локальности» Иркутска не распределены равномерно по территории города, а концентрируются в историческом центре. В интервью и публикациях городских медиа хорошо читаются изменения ментальной карты «китайского» Иркутска, охватывающей наиболее знаковые символы города и региона:

В нынешнем году нашествие туристов из КНР уже невозможно не заметить. Они повсюду: на улице Карла Маркса, на Урицкого и, естественно, на Байкале. Если вы решите проехать по КБЖД, то не удивляйтесь, что большинство ваших соседей по вагону будут китайцы. <..> Гиды перечисляют излюбленные локации китайских туристов: Казанская церковь, 130-й квартал и, конечно, «Тальцы» (Старшинина 2016).

Важной переменой географии «китайского» Иркутска стало не только изменение локации присутствия китайцев, но и размывание границ таких локальностей. Одним из условий консенсуса о «старых китайских локальностях» являлась относительная устойчивость и односторонняя проницаемость их границ: горожане могли свободно пересекать ее в рамках допустимого репертуара практик, тогда как мигрантам приписывалась и предписывалась замкнутая жизнь в таких локальностях по модели gated living (Grigorichev 2016). Формирование новой системы «китайских» пространств происходит постепенно, что создает не только эффект новой географии, но и представление о неустойчивости их границ. Как следствие, эффект перемещения китайцев из привычных локальностей в центр города оказался дополнен острым ощущением их «неконтролируемого расползания», вероломного нарушения сложившейся конвенции о доступе к городским пространствам и инфраструктуре, праве на участие в жизни города.

Новые китайские локальности города маркируются и новой визуальностью. Ее основным элементом стала реклама на китайском языке. Выполненная, как правило, в лаконичной и очень функциональной манере, она 
обозначает China friendly места. Важнейшим отличием новых визуальных символов присутствия китайцев является практически полное отсутствие узнаваемых стереотипизированных элементов, отражающих устоявшееся представление о «китайской культуре». Здесь почти невозможно встретить «китайских» драконов, «классического» сочетания красного и золотого цвета, очертаний пагод. Вывески, ценники и информационные стенды ориентированы на самих китайцев, а не на жителей Иркутска. Выбор целевой аудитории смещает акцент именно на иероглифические надписи, которые доминируют в вывесках и иной рекламе. В результате новые визуальные приметы взаимодействия китайцев с городом для горожан остаются нечитаемыми, а потому- «неправильными», отражающими появление в городском пространстве «неправильной китайскости» и локальностей, где набор допустимых практик не определен, а потому взаимодействие невозможно.

Новые элементы вкрапляются в привычную городскую визуальность. Появление иероглифического текста на вывесках становится признаком «скупки» городской инфраструктуры приезжими. В прочтении горожан появление такой символики означает не попытку местного бизнеса привлечь новых клиентов, а приобретение местного бизнеса приезжими; этот бизнес, как предполагается, «обслуживает только китайщев, налогов не платит, а все деньги выводит в Китай» (ж., около 30 лет, интервью 2018 г.). В результате Иркутск контекстуально вводится в перспективу своего рода «обратного ориентализма», когда город описывается в ключе процесса превращения в торговую факторию новых колонизаторов:

Знаете, мне последнее время кажется, что наш Иркутск превращается в Маньчжурию. Это такой город в Китае, знаете, на границе? Там китайцы нашим все впаривают, и кроме торговли ничего нет. И города как бы даже и нет... Вот у меня ощущение, что мы теперь стали как бы такой границей, где нормального Иркутска почти не осталось совсем (ж., около 25 лет, интервью 2017 г.).

Здесь город не просто присваивается чужаками, а оказывается на грани исчезновения, растворения в бескрайнем просторе перевернутого «китайского» рынка, где местные жители выступают продавцами, а приезжие из КНР - скупщиками за бесценок народных богатств. Показательно, что именно мотивы неравноценного и невыгодного взаимодействия с китайцами наиболее часто встречаются в комментариях к новостям и публикациям о миграции из Китая. Следствием перемен стало радикальное переопределение «китайских» мест города. Респонденты уверенно описывают новые городские локальности, ассоциирующиеся у них с китайцами и китайскостью:

O: Китайские места Иркутска? Легко [назову]! [Улица] Карла Маркса, набережная, памятник Александру III, весь 130-й квартал , и, конечно, магазины!

${ }^{1}$ Торгово-рекреационное пространство Иркутска, стилизованное под застройку рубежа XIX-XX вв., и сосредотачивающее значительное число ресторанов и магазинов. 
В.: Какие магазины?

О.: Да всякие. Ювелирные и прочие лакшери. И даже продуктовые.

Да все туристические места, где они нас скупают (м., около 25-27 лет, интервью 2017 г.).

В качестве «китайских» уверенно определяются локальности, которые прежде не ассоциировались с приезжими из Китая, например, православная Казанская церковь. Ключевым аргументом, позволяющим, на взгляд респондентов, определить ее в таком качестве, является возможность оплатить покупки в церковной лавке юанями:

О.: Туда китайцы любят ходить. Красивая, яркая... Но дело не в этом. Там за иконки, свечки, и ну и всякое такое, можно юанями расплатиться. Они охотно берут.

В.: Китайцы?

О.: Нет, я про этих... служащих... Ну, в церкви которые... Они юани берут (ж., около 30 лет, интервью 2017 г.).

Таким образом, ключевым критерием «китайскости» обозначенных локальностей выступают новые практики взаимодействия приезжих с городом и новая позиция мигрантов в этих отношениях. В интервью это емко выражено определением «где они нас скупают». Если прежде приезжий из Китая-это продавец товаров или услуг, то теперь- обеспеченный, а потому имеющий возможность выбирать потребитель. Иная позиция и декорации обусловливают и другие исполнения, очевидные и единственно возможные для китайцев, и нередко неприемлемые для горожан:

Знаете, когда я их [китайских туристов] вижу, вот в этих местах, буквально в самом центре [города], где самая история... мне часто кажется, что гастарбайтеры со стройки сбежали. Что они тут делают? Неправильно как-то это... И сами они неправильные (ж., 23 года, интервью 2017 г.).

Такая «неправильность» поведения приезжих из КНР отмечается не только респондентами и авторами постов в социальных медиа, но и в академической среде. Здесь поиск причин такой ситуации уводит участников дискуссий в плоскость различий России и Китая и даже извечного киплинговского противостояния Запада и Востока (Круглый стол 2017). Однако отчетливо прослеживается разведение «правильных» китайцев на рынках и стройках и «неправильных»- в магазинах и в ресторанах. Неслучайно малоприметные и сдержанные символы новых «китайских» локальностей города вызывают отторжение и острую реакцию в отличие от ярких, кричащих о своей «китайской» природе символов прежних лет. Показательно, что респонденты нередко не замечают привычные символы «китайской» локальности на фоне малозаметных информационных стендов, написанных иероглифами:

O: Там вот такой стенд стоит, почти неприметный, но там все-все написано, какие камни у нас покупать. 
В.: Это там, где китайский ресторанчик? Там еще на веранде дракон такой стоит.

О.: Не знаю... Вроде, да. Есть там что-то такое, не помню (м., около 30 лет, интервью 2017 г.).

Символика «китайских локальностей» обозначала место встречи и контакта, происходивших в конвенциальных границах допустимого репертуара практик и коммуникационных стратегий, а теперь маркирует, скорее, оспариваемые городские пространства. Примечательно, что китайские туристы новых смыслов в городские локальности не вкладывают, для них Иркутск- один из нескольких городов, которые они посетят один раз и куда, вероятно, никогда не вернутся. Символическое присвоение города здесь происходит скорее через представления горожан, для которых появление новой, «неправильной» китайскости означает вызов их праву на город. Размывание границ четко очерченных локальностей контакта с другим создает ощущение, что город полностью поглощается этим пространством, утрачивая свою идентичность.

«Неправильность» «новых китайских локальностей», как символ разрушения прежнего консенсуса, порождает представление о посягательстве китайцев на городское пространство. Нередко в региональных СМИ и социальных медиа новая «миграционная ситуация» в городе описывается как «неправильная», «недопустимая», «захватническая». Приезжие из Китая независимо от реального статуса (туристы, трудовые мигранты, постоянные жители) рассматриваются в качестве «захватчиков», «оккупантов», виновников многочисленных неудобств. Меняющаяся символика интерпретируется как признак изменения пространства репрезентаций (Лефевр 2015: 52) и вторжение в «обжитое пространство» горожан. Именно с «китайцами» связывается представления о переопределении функций городских локальностей (из места для жизни в место «скупки»), вытеснении горожан из общественных пространств, болезненными изменениями пространственной практики. Сами китайские туристы невольно выступают здесь субъектом, который пытается присвоить пространство города.

\section{Заключение}

Интерпретация горожанами «старых» и «новых» китайских локальностей Иркутска создает две принципиально разные картины присутствия «китайцев» в городе и отношения горожан с ними по поводу права на городское пространство. В первом случае «китайские» локальности оказываются «местом встречи», площадкой совместного создания и использования городской инфраструктуры, во втором- пространством конфликта, борьбы за город. Включение «местных сражений» в глобальную повестку политики выступает здесь механизмом легитимации приоритетного права 
на город. Экономическая основа этих процессов выносится за скобки, уступая место иррациональной борьбе с «глобальными угрозами».

Парадоксом является то, что символика «старых китайских локальностей» производится мигрантами и репрезентирует именно присутствие мигрантов, их экономическую деятельность. Напротив, визуальность «новых китайских локальностей» продуцируется в основном «местными». Распространенное представление о том, что все объекты городской инфраструктуры, обслуживающие китайцев и маркированные China friendly, принадлежат «на самом деле» китайскому бизнесу, в полевых наблюдениях не находят подтверждения. Напротив, включенное наблюдение 2018-2019 гг. позволяет заметить, что локальный бизнес активно пытается привлекать группы китайских туристов, в том числе, через маркирование своих объектов China friendly символикой (вывески на китайском, обслуживание по картам UnionPay и по платежной системе WeChat).

В этой перспективе приезжие из Китая участвуют в оспаривании городского пространства едва ли не против своей воли, а скорее даже не подозревают о своем участии в борьбе за «право на город». Новые смыслы в общественные городские пространства они привносят почти исключительно самим фактом своего недолгого, но очень заметного присутствия. В этом кроется еще одно важное отличие новой волны приезжих из Китая от трудовых и торговых мигрантов из КНР девяностых и нулевых: туристы, сколь бы ни были велики их группы, не претендуют на собственное прочтение пространства Иркутска и символическое его присвоение. Напротив, ключевыми акторами в конструировании ситуации оспаривания пространства оказываются горожане и местные медиа, тогда как мигранты включены в этот процесс лишь пассивно. Именно принимающее сообщество оказывается активным интерпретатором новой символики городского ландшафта и автором логических конструкций, обосновывающих претензии приезжих на пространство города. Конструирование ситуации оспаривания пространства выступает предпосылкой для выработки новых практик взаимодействия с качественно новой миграцией. Изменение моделей поведения другого подталкивает к поискам нового репертуара допустимых исполнений, и именно конфликт становится источником для них. Если другой не участвует в конструировании такого конфликта, то за него это делает принимающее сообщество.

В пользу этого тезиса свидетельствует история появления и включения в городскую повседневность «старых китайских локальностей». Достаточно вспомнить образы «китайских» рынков, широко бытовавшие в медиа, где мотивы «поглощения» и даже «оккупации» городского пространства присутствовали широко и красочно (Дятлов 2014). Но с формированием консенсуса о допустимых границах сцены соперничество почти полностью ушло в сферу медиа и властной риторики, не пересекаясь с повседневностью горожан. Это позволяет предположить, что конструирование ситуации 
оспаривания городского пространства является закономерным и неизбежным этапом формирования нового набора практик взаимодействия с другим. Спецификой российской ситуации является погружение миграционных процессов в этнический контекст, который в медийном и общественном дискурсе быстро уходит в расовую, а иногда и расистскую риторику. Однако, как показывает опыт включения российских городов в систему иных масштабных трансграничных миграций, по мере выработки нового консенсуса о границах городской сцены для встречи с другим и допустимых исполнениях, риторика борьбы уходит из повседневных практик, уступая место рациональным формам социального взаимодействия.

\section{Выражение признательности}

Исследование выполнено при поддержке РНФ, проект № 18-18-00293.

\section{Список источников}

Адамайтес А. (2018) Китайць заявляют, что Сибирь-их территория. Комсомольская правда-Алтай. Доступно по ссылке: https://www.alt.kp.ru/daily/26914.4/3959543/ (дата обращения: 29 сентября 2020).

Гофман И. (2004) Анализ фреймов. Эссе об организаџии повседневного опыта. М.: Общественное мнение.

Григоричев К.В., Дятлов В.И., Тимошкин Д. О., Брязгина Д. Е. (2019) Базар и город: люди, пространства, образы. Иркутск: Оттиск.

Дятлов В.И. (2014) «Китайский» рынок «Шанхай» в Иркутске: роль в жизни городского сообщества. Известия Иркутского государственного университета. Серия: Политология. Религиоведение, (10): 103-119.

Дятлов В.И., Кузнецов Р.Э. (2004) «Шанхай» в центре Иркутска. Экология китайского рынка. Экономическая соичология, 5 (4): 56-71.

Дятлова Е.В. (2015) Китайский общепит в процессе этнизации городского пространства (на примере Иркутска). В: В.И. Дятлов, К.В. Григоричев (ред.) Этнические рынки в России: пространство торга и место встречи. Иркутск: Иркутский государственный университет: 171-186.

Зиммель Г. (2008) Экскурс о чужаке. А. Ф. Филиппов (ред.) Социологическая теория: история, современность, перспективы. СПб.: Владимир Даль:9-14.

Иркутск онлайн (2017) Увеличение потока китайских туристов: сплошные плюсы? Доступно по ссылке: https://www.irk.ru/tourism/blog/20170504/china/ (дата обращения: 03 июля 2018).

Краснопольская И.И., Солодова Г.С. (2012) Восприятие чужака группой в социологии Г. Зиммеля. Социологический журнал, (4):24-35.

Круглый стол (2017) «Востокозапад». Проект Байкал, (54): 46-53. 
Лефевр А. (2015) Производство пространства. М.: Strelka Press.

Сальникова О. (2020) Недорогие туристы. Выгодны ли Петербургу гости из Китая? Аргументы и Факты-Петербург, (1-2): 3.

Старшинина Е. (2016) Китайцы скупают Иркутск. Baikal-info.ru. Доступно по ссылке: http://baikal-info.ru/kitaycy-skupayut-irkutsk (дата обращения: 3 июля 2018).

Тимошкин Д. О. (2018) Выживание, экзотика, пустота: эволюция «постсоветского» открытого рынка в городских нарративах. Социологический журнал, 24 (4): 54-74.

Dürr E. (2002) Contested Urban Space Symbolizing Power and Identity in the City of Albuquerque, USA. In: F. Colombijn, A. Erdentug (ed.) Urban Ethnic Encounters. London: Routledge:209-225.

Grigorichev K. (2016) Migrant Localities: 'Gated Space' or 'Access Points'? Journal of Siberian Federal University. Humanities \& Social Sciences, 9 (4): 783-794.

Harvey D. (2006) The Right to the City. In: R. Scholar (ed.) Divided Cities: The Oxford Amnesty Lectures 2003. Oxford: Oxford University Press: 83-103.

Lefebvre H. (2000) Writing on City. Oxford: Blackwell.

Mitchell D. (2003) The Right to the City: Social Justice and the Fight for Public Space. New York: The Guilford Press.

Reyes R.C. (2016) Public Space as Contested Space: The Battle over the Use, Meaning and Function of Public Space. International Journal of Social Science and Humanity, 6 (3): 201-207. 
Konstantin Grigorichev

\section{THE 'WRONG' TYPE OF CHINESE AND THE 'CAPTURED' CITY: CONTESTING OF URBAN SPACES AND CONSTRUCTING PRACTICES OF INTERACTING WITH THE 'OTHER'}

The article analyses the process of constructing disputed urban spaces in connection with a change in migration flows from China. The analysis is based on two series (2014-2017 and 2017-2019) of semi-structured interviews in Irkutsk in the framework of the ideas of the 'right to the city'. A comparative analysis of two types of urban localities, defined by the townspeople as 'migrant' and 'Chinese', is carried out. From the late 1980s, stable localities have been formed that are described as 'Chinese': open-air markets, car repair shops, restaurants. Its 'Chineseness' pointed not so much to the dominant group as to the repertoire of acceptable practices of interacting with the 'Other'. The mass entry of tourists from China later on led to the emergence of new urban spaces, described by residents and media as 'Chinese'. Its visual markers became a symbol of violation of convention on the possible places and practices of interaction between citizens and migrants. New symbolism is interpreted by the host community as a sign of a change in the space of representations and an invasion of the 'habitable space' of citizens. If earlier 'Chinese' locales have acted as a 'meeting place', a platform for the joint creation and use of urban infrastructure, then now they are a space of conflict, a struggle for the city. The redefinition of migrant urban localities from the place of contact to the space of contesting the right to the city can be a mechanism for developing a new range of interaction practices. Changing the 'Other' requires a new repertoire of permissible performances, and it is precisely conflict that allows us to determine new boundaries for the permissible and approved.

Key words: migrant localities, 'Chineseness', migration, contested spaces

DOI: $10.17323 / 727-0634-2020-18-4-593-608$

\section{References}

Adamaite A. (2018) Kitaitsy zayavlyaut chto Sibir- ikh territoriya [The Chinese Claim that Siberia is their Territory]. Komsomol'skya Pravda-Altai. Available at: https://www.alt.kp.ru/ daily/26914.4/3959543/ (accessed 29.09.2020).

Dürr E. (2002) Contested Urban Space Symbolizing Power and Identity in the City of Albuquerque, USA. In: F. Colombijn, A. Erdentug (ed.) Urban Ethnic Encounters. London: Routledge: $209-225$.

Konstantin V. Grigorichev- Dr. Sci. (Soc.), Vice-Rector for Research and International Cooperation, Irkutsk State University; Leading Researcher, National Research Tomsk State University, Irkutsk, Russian Federation. Email: grigoritchev@yandex.ru 
Dyatlov V.I. (2014) 'Kitayskiy' rynok 'Shankhay' v Irkutske: rol' v zhizni gorodskogo soobshchestva ['Chinese' Market 'Shanghai' in Irkutsk: Its Role in the Urban Community Life]. Izvestiya Irkutskogo gosudarstvennogo universiteta. Seriya: Politologiya. Religiovedenie [The Bulletin of Irkutsk State University. Series Political Science and Religion Studies], (10): 103-119.

Dyatlov V.I., Kuznetsov R. E. (2004) 'Shanghai' v centre Irkutska. Ekologiya kitaiskogo rynka ['Shanghai' in the center of Irkutsk. Ecology of the Chinese market]. Ekonomicheskaya sociologia [Economic sociology], 5 (4): 56-71.

Dyatlova E. V. (2015) Kitayskiy obshchepit v protsesse etnizatsii gorodskogo prostranstva (na primere Irkutska) [Chinese Public Catering in the Process of Urban Space Ethnicization (The Case of Irkutsk)]. In: V.I. Dyatlov, K.V. Grigorichev (eds.) Etnicheskie rynki v Rossii: prostranstvo torga $i$ mesto vstrechi [Ethnic Markets in Russia: Space of Bargaining and Place of Meeting]. Irkutsk: Irkutskiy gosudarstvennyy universitet: 171-186.

Goffman E. (2004) Analiz freymov. Esse ob organizatsii povsednevnogo opyta [Frame Analysis: An Essay on the Organization of Experience]. Moscow: Obshchestvennoe mnenie.

Grigorichev K. (2016) Migrant Localities: 'Gated Space' or 'Access Points'? Journal of Siberian Federal University. Humanities \& Social Sciences, 9 (4): 783-794.

Grigorichev K. V., Dyatlov V.I., Timoshkin D. O., Bryazgina D. E. (2019) Bazar i gorod: lyudi, prostranstva, obrazy [The Bazaar and the City: People, Spaces, Images]. Irkutsk: Ottisk.

Harvey D. (2006) The Right to the City. In: R. Scholar (ed.) Divided Cities: The Oxford Amnesty Lectures 2003. Oxford: Oxford University Press: 83-103.

Irkutsk online (2017) Uvelichenie potoka kitayskikh turistov: sploshnye plyusy? [The Increase of the Chinese Tourists Flow: Solid Pluses?]. Available at: https://www.irk.ru/tourism/blog/20170504/china/ (accessed 3.07.2018).

Krasnopolskaya I.I., Solodova G. S. (2012) Vospriyatie chuzhaka gruppoy v sotsiologii G. Zimmelya [Group Perception of a Stranger in G. Simmel Sociology]. Sotsiologicheskiy zhurnal [Sociological Journal], (4):24-35.

Lefebvre H. (2000) Writing on City. Oxford: Blackwell.

Lefebvre H. (2015) Proizvodstvo prostranstva [The Production of the Space]. Moscow: Strelka Press.

Mitchell D. (2003) The Right to the City: Social Justice and the Fight for Public Space. New York: The Guilford Press.

Reyes R.C. (2016) Public Space as Contested Space: The Battle over the Use, Meaning and Function of Public Space. International Journal of Social Science and Humanity, 6 (3): 201-207.

Round table (2017) Vostokozapad [Eastwest]. Proekt Baykal [Project Baikal], (54): 46-53.

Salnikova O. (2020) Nedorogie turisty. Vygodny li Peterburgu gosti iz Kitaya? [Inexpensive Tourists. Are Guests from China Profitable for St. Petersburg?]. Argumenty I fakty-Peterburg [Arguments and Facts- Petersburg], (1-2):3.

Simmel G. (2008) Ekskurs o chuzhake [The Stranger]. In: A. F. Filippov (ed.) Sotsiologicheskaya teoriya: istoriya, sovremennost', perspektivy [Sociological Theory: History, Modernity, Prospects]. St. Petersburg.: Vladimir Dal': 9-14.

Starshinina E. (2016) Kitaytsy skupayut Irkutsk [The Chinese are Buying up Irkutsk]. Available at: http://baikal-info.ru/kitaycy-skupayut-irkutsk (accessed 3 July 2018).

Timoshkin D. O. (2018) Vyzhivanie, ekzotika, pustota: evolyutsiya 'postsovetskogo' otkrytogo rynka v gorodskikh narrativakh [Survival, Exotica and Emptiness: The Evolution of the Post-Soviet open Market in Urban Narratives]. Sotsiologicheskiy zhurnal [Sociological Journal], 24 (4): 54-74. 